\title{
Colonizing landscapes/landscaping colonies: from a global history of landscapism to the contemporary landscape approach in nature conservation
}

\author{
Jevgeniy Bluwstein ${ }^{1}$ \\ University of Fribourg, Switzerland \\ Preprint July 2021
}

\begin{abstract}
I suggest that to decolonize conservation we must also decolonize our way of seeing land and nature-society relations inscribed in it as landscapes. I proceed in three parts. First, drawing on insights from post- and decolonial studies, critical geography, environmental history and political ecology, I highlight three problems that underpin a landscape way of seeing nature-society relations: depoliticization, simplification/ decomplexification, and representation. Second, to illustrate the colonial legacy of the contemporary landscape approach to nature conservation, I revisit the global history of landscapism - the double movement of colonizing landscapes/landscaping colonies. This double movement began with the internal colonization of European landscapes (autonomous political communities), and continued through the landscaping of (settler-)colonies by Europeans outside of their homelands. Third, through the contemporary case of a landscape conservation initiative in Tanzania (the so-called "Tarangire-Manyara Ecosystem"), I illustrate the implications of the double movement in the colonial present of African conservation. I conclude with a few remarks on what decolonization of conservation would have to entail in scientific research and practice.
\end{abstract}

Keywords: landscapes, landscape approach, nature conservation, coloniality, decolonization

\section{Résumé}

Je suggère que pour décoloniser la protection de la nature, nous devons également décoloniser notre façon de voir la terre, et les relations nature-société qui s'y inscrivent, comme les paysages. Je procède en trois parties. Tout d'abord, je m'appuie sur les connaissances des études postcoloniales et décoloniales, de la géographie critique, de l'histoire environnementale et de la «political ecology». Trois problématiques sous-tendent la manière de saisir l'expression des relations nature-société comme le paysage: la dépolitisation, la simplification/décomplexification et la représentation. Deuxièmement, pour illustrer l'héritage colonial de l'approche paysagère contemporaine dans la protection de la nature, je revisite l'histoire globale du paysage le double mouvement des paysages de la colonisation/colonies paysagères. Ce double mouvement a commencé avec la colonisation interne des paysages européens (dans les communautés politiques autonomes), et s'est poursuivi à travers l'aménagement paysager des colonies (de peuplement) par les Européens en dehors de leurs pays d'origine. Troisièmement, j'illustre les implications du double mouvement dans le présent colonial de la protection africaine de la nature, à travers le cas contemporain d'une initiative de protection du paysage en Tanzanie (le soi-disant «écosystème Tarangire-Manyara»). Je conclus par quelques remarques sur ce que la décolonisation de la protection devrait impliquer dans la recherche et la pratique scientifiques.

Mots-clés: paysages, approche paysagère, conservation de la nature, colonialité, décolonisation

\footnotetext{
${ }^{1}$ Dr. Jevgeniy Bluwstein, Senior Lecturer in Human Geography, Department of Geosciences, University of Fribourg, Switzerland. Email: jevgeniy.bluwstein "at" unifr.ch. This article benefitted from comments and feedback by the special issue editors Dan Brockington, Esteve Corbera and Sara Maestre, three anonymous reviewers, friends and colleagues. Kudos to Simon Batterbury for keeping JPE alive and flourishing! This is the xx article in Dan Brockington, Esteve Corbera and Sara Maestre (eds.). 2021. "The challenges of decolonizing conservation", Special Section of the Journal of Political Ecology 28.
} 


\section{Resumen}

En este artículo sugiero que para descolonizar la conservación también debemos descolonizar nuestra forma de entender la tierra y las relaciones naturaleza-sociedad inscritas en ella como paisajes. Procedo en tres partes. Primero, basándome en las ideas de los estudios poscoloniales y decoloniales, la geografía crítica, la historia ambiental y la ecología política, destaco tres problemas que sustentan una forma de ver las relaciones naturaleza-sociedad desde la perspectiva de paisaje: despolitización, simplificación / descomplejización y representación. En segundo lugar, para ilustrar el legado colonial del enfoque del paisaje contemporáneo en el terreno de la conservación de la naturaleza, revisito la historia global del paisajismo: el doble movimiento de colonizar paisajes / "paisajar" las colonias . Este doble movimiento comenzó con la colonización interna de los paisajes europeos (comunidades políticas autónomas) y continuó a través del paisajismo de las colonias (de los colonos) por parte de los europeos fuera de sus países de origen. En tercer lugar, a través del caso contemporáneo de una iniciativa de conservación del paisaje en Tanzania (el llamado "Ecosistema TarangireManyara"), ilustro las implicaciones del doble movimiento en el presente colonial de la conservación africana. Concluyo con algunas observaciones sobre lo que tendría que implicar la descolonización de la conservación en la investigación y la práctica científicas.

Palabras-clave: Palabras clave: paisajes, enfoque paisajístico, conservación de la naturaleza, colonialidad, descolonización

\section{Introduction}

I suggest that to decolonize conservation - the theme of the Special Section that this article is part of we must also decolonize our way of seeing land and nature-society relations inscribed in it as landscapes. Before I lay out my contention with landscapes, a brief review is warranted of this slippery, ambiguous, ambivalent, confusing, and yet politically powerful and analytically productive concept (Minca, 2007a; Minca, 2007b; Wylie, 2007).

The notion of "landscape" has undergone several turns in geography and related disciplines. From the $18^{\text {th }}$ century until the first half of the $20^{\text {th }}$ century, the idea of objectively perceivable physical landscapes with specific natural and cultural properties prevailed. Usually associated with Carl Sauer and the Berkeley School, landscapes were studied through empirical, descriptive, first-hand observations (Wylie, 2007). The quantitative turn in geography in the 1960s led to a disciplinary shift, privileging space over landscape as an analytical concept. While a positivist geography abandoned landscapes as objects of analysis, a new cultural geography revived them beginning in the 1970s (Kühne et al., 2019; Neumann, 2011; Wylie, 2007). On the one hand, landscapes came to be understood historically and culturally as particular modes of seeing, observing and knowing the world. From this vantage point, a critical engagement with landscapes focused on examining references to landscapes in art, literature, and science as vehicles of vested interests and regimes of power (Wylie, 2007). On the other hand, landscapes were also examined phenomenologically as cultural practices of embodiment, inhabitation, dwelling, belonging and myth making (Wylie, 2007). In part, landscape phenomenologists reintroduced Carl Sauer's approach, however without the positivist underpinnings. Taken together, the variety of engagements with the notion of landscape in cultural geography, anthropology, political ecology and environmental history highlights its politically contentious and conflicted, ideological, imaginative, discursive, material and embodied dimensions (Berr \& Schenk, 2019; Kühne et al., 2019; Beardsley, 2016; Neumann, 2011; Mitchell, 2001; Görg, 2007; Wylie, 2007).

For the purpose of this article - advancing a post- and decolonial critique of the landscape approach to conservation - I highlight those insights from critical landscape studies that combine poststructural and materialist perspectives. These perspectives associate landscape thinking with vehicles of vested interests and regimes of power written on the land, hence, as a set of practices of symbolic and material appropriation and exclusion (Wylie, 2007, p. 14). For instance, Marxist geographer Don Mitchell sees landscape as "a relationship of alienation" (Mitchell, 2001, p. 272) and cultural historian Raymond Williams insists that "[t]he very idea of landscape implies separation and observation" (Williams, 1975, p.120). To Mitchell, there is a historical lineage between the violent genealogy of property as shown by Nick Blomley (1998) and the material and symbolic construction of landscapes. These insights from North America and England resonate with the political ecology of conservation in East Africa as highlighted by geographer Rod Neumann (1998). Neumann (1998, p. 3) traces 
how the colonial idea of a "scenic African landscape" traveled from Europe to Tanganyika to reclaim ancestral territories of rural land and resource use as wilderness areas for Western nature consumption and (post)colonial state control. To Neumann, this was a "contestation over landscape meaning and representation" (1998, p. 176). Drawing on work in Southeast and South Asia, physical and human geographers Daniel Friess and Tariq Jazeel (2017, p. 15) propose that landscapes defined as spatially bounded containers "exclude or obscure other kinds of geographies, other claims, and other spatial experiences and intuitions." This leads the authors to see landscape as "a narrative, one that is spatially and taxonomically partial, exclusive, and duplicitous." Environmental historians Thomas Lekan and Thomas Zeller (2014, p. 26) conclude in their extensive review that historians and geographers understand the landscape phenomenon as "the nexus between the material and the visual, between appropriation and appreciation."

These insights suggest that landscape is above all a powerful idea with material consequences. Rather than taking landscapes for granted as given spaces where nature and culture meet, we should begin our inquiry by paying attention to landscapism ${ }^{2}$, how the idea of landscape is mobilized to see, know, and intervene in nature-society relations. Such critical insights have been largely ignored by positivist geographers and related disciplines who continue studying landscapes today, and even poststructuralist analyses tend to believe in the objective reality of landscapes as spatial containers (Minca, 2007a). Conservation and environmental sciences have even embraced a new objectivist landscape turn since the 1990s, which posits that socio-ecological systems and associated environmental problems can be best understood and intervened in through the so-called landscape approach. This approach has paved the way for the revival of a landscape concept as an $a$ priori given space and container with particular ecological, biophysical and cultural properties - nature-society relations - that can be objectively determined through a positivist methodology of field-based observations, geospatial analytics, modelling and quantification (Poerting \& Marquardt, 2019; Weber \& Kühne, 2019).

The promise of the landscape approach to conservation and environmental sciences lies in conceptualizing nature-society relations in a more comprehensive, holistic fashion by including and balancing the needs of different stakeholders in order to achieve social, economic, environmental, cultural, and to some degree political objectives (Reed et al., 2017). The landscape approach thus suggests that a "true", total representation of nature-society relations in space is possible and desirable, if only all stakeholders contribute to describing the landscape's inventory - its natural and cultural elements and objects (Minca, 2007a). Here, I argue that the landscape approach to nature-society relations suffers from three related problems. First, it depoliticizes the stakes in nature-society relations by rendering analysis of and interventions in environmental problems as technical issues. Second, it simplifies and decomplexifies nature-society relations through positivist epistemologies. Third, it promotes exclusion through representation, a colonial logic of a landscape way of seeing which is applied to improve these relations.

Whereas the problem of depoliticization is well known in political ecology, geography and development studies, I draw on decolonial studies to go beyond this critique to examine the other two problems. Decolonization is usually understood as a demand for a critical awareness, and the unsettling and undoing of colonial legacies of knowledge-making in scholarship and everyday life (de Leeuw \& Hunt, 2018; Mbembe, 2015; Sundberg, 2014). Colonial legacies manifest themselves at the symbolic level through the exercise of power in classifying, making legible, representing, and evaluating specific peoples, places, ecologies, in short, nature-society relations (West, 2016; Ndlovu-Gatsheni, 2015; Grosfoguel, 2007; Smith, 1999; Scott, 1998; Mitchell, 1991). This power is exercised through the reduction of complex socio-ecological relations into a universalizing, positivist, western-Cartesian framework (Goldman, 2020; Sungusia et al., 2020; Mignolo, 2011; Smith, 1999). Critical of these power relations, decolonial and post-colonial perspectives emphasize how (scientific) knowledge can become a form of epistemic violence (Spivak, 1988) when alternative voices and world views - what Foucault (2003) called "subjugated knowledges" - are marginalized, silenced or erased through the authority of knowledge production and expertise (Amo-Agyemang, 2021; Todd, 2016; Mbembe, 2015; Davis, 2007; Adams \& Mulligan, 2003).

\footnotetext{
${ }^{2}$ What I propose to call landscapism echoes Bernard Debarbieux' empaysagement, a neologism for our contemporary "invocation of landscape and of landscape concerns in any form of intervention" (Debarbieux, 2011, p. 141).
} 
However, decolonization is not about integrating local, marginalized, subaltern knowledges into scientific practices (Goldman, 2020). On the contrary, decolonization begins with epistemic disobedience (Mignolo, 2011). Importantly, demands for decolonization do not stop with the domain of science and knowledge production. Above all, land has to be given back and colonial property relations dismantled where they persist in settler- or post-colonial contexts (Tuck and Yang, 2012). From this vantage point, I understand calls to decolonize conservation as a questioning and overcoming of "the biopolitical and geopolitical management of people, land, flora and fauna" (Tuck \& Yang 2012, p. 4). The point of decolonization is thus not to reconcile present grievances or to foreclose future conflict. Rather than reconciling tensions and settling conflicts, decolonization is an unsettling affair (Tuck \& Yang, 2012). Ultimately, Tuck and Yang (2012) insist that we need to attend to the irreconcilable in colonial structures and legacies, if we take decolonization seriously.

So what is irreconcilable in the landscape approach to conservation that cannot be settled? I argue that the landscape way of seeing imbues conservation and environmental scientists and practitioners with the power to represent people and their relationships to land and environment ${ }^{3}$. Representation is central to how cultural geographers understand the power of a landscape way of seeing in science and modernity. Representation is a particular epistemological model, an elevated, seemingly objective and detached vantage point from which one looks at the assemblage of land, people, and the environment (in short, nature-society relations) as a landscape (Wylie, 2007). Given that natural science methodologies are the preferred choices in landscape-based analysis and intervention, there is a tendency in the landscape approach to conservation to simplify and erase socioecological complexity and more-than-human relationality that make up the socionatural fabric. This sort of scientific rationalization is at once an exercise of power to represent and an illustration of the limits of representation (Dalton et al., 2019; Massey, 2005). As I will show, conservation and environmental science cannot reconcile and settle this tension, because the way in which landscapism represents nature-society relations is a fundamentally exclusive perspective, which is "implicated in the general operations of colonizing power" (Gregory, 2001, p. 93).

To be sure, a post- and decolonial critique of the landscape approach to conservation will resonate more strongly outside of Europe than within. In post-war Europe, contemporary conservation initiatives face the problem of collective action, the question of how different stakeholders can be mobilized to jointly work together towards environmental goals in a given landscape (Adams et al., 2016). ${ }^{4}$ In many regions outside of Europe, particularly in imperial and post- or settler-colonial settings (Davis and Burke, 2011), the challenge of collective action for conservation is overshadowed by the politics of landscape belonging, the question of whose landscape vision counts and who is included and excluded within this vision (Toomey, 2020; Friess \& Jazeel, 2017; Willems-Braun, 1997). Yet, as I will show, we still need to begin in Europe, if we want to understand how the landscape way of seeing has colonized the world.

In what follows, Section 2 reconstructs the recent rise of the landscape approach in nature conservation as landscapism's contemporary manifestation. Section 3 revisits the history of landscapism to illustrate historical continuities from past to present, what I call the double movement of colonizing landscapes/landscaping colonies. Section 4 zooms in on the African continent and a case study from Tanzania to illustrate the implications of landscapism in contemporary nature conservation. The article concludes with a few remarks on what decolonization of conservation would have to entail in research and practice.

\section{The rise of the landscape approach in nature conservation}

Arts et al. (2017) offer a useful definition of the landscape approach by distinguishing between two main ways as to how it is applied today. On the one hand, the landscape approach is invoked as an analytical concept

\footnotetext{
${ }^{3}$ Here I need to draw on post-colonial thought, because - to my knowledge - a decolonial critique of a 'landscape way of seeing' is yet to be articulated. See Ndlovu-Gatsheni (2015) for how decolonial and post-colonial perspectives converge and diverge. Some scholars working in the decolonial tradition may take issue with my attempt to formulate a decolonial critique of a landscape way of seeing by drawing on a western canon (e.g. Todd, 2016; Grosfoguel, 2007). I welcome similar or different attempts by others, drawing on non-western literatures.

${ }^{4}$ But see Iordachescu (2021) for a case from Romania that points to important exceptions.
} 
to integrate different disciplines concerned with land and resource use, drawing on landscape as a spatially and ecologically defined unit that cuts across different sectors and scales (Arts et al., 2017). The authors cite DeFries and Rosenzweig (2010, p. 19630) to illustrate a good example of an analytical conceptualization of the landscape approach: "analyses of options at local, national, continental, or global scales require a wholelandscape approach that incorporates the full spatial, temporal, and socioeconomic domains." On the other hand, the landscape approach is employed as a strategic concept to integrate different land and resource uses to address environmental problems at a particular scale (Arts et al., 2017). Here, the authors draw on the definition provided by Reed et al. (2015, p. 1) who understand the landscape approach as a "framework to integrate policy and practice for multiple land uses, within a given area, to ensure equitable and sustainable use of land while strengthening measures to mitigate and adapt to climate change." Taken together, these two arms of the landscape approach - the analytical and the strategic - invite us to look through the landscape lens when thinking about and planning to intervene in climate and land use change, nature and biodiversity conservation.

The growing popularity of the landscape approach initially drew on integrated approaches to spatial planning and was inspired by nature conservation strategies in the global North as well as debates about tradeoffs between conservation and rural livelihoods in the global South (Arts et al., 2017). In the 1990s landscape thinking was increasingly linked to the 'sustainable development' agenda while conservation science and initiatives further broadened the scope of the landscape approach beyond development, towards socioecological considerations (Arts et al., 2017). Today, the question of ecological connectivity (and its flipside fragmentation) dominates landscape thinking in conservation and environmental sciences (Helfenstein et al., 2014; Worboys et al., 2010).

This evolution towards the presently popular landscape approach converged with broader developments in conservation science and practice of the past century. By the mid- $20^{\text {th }}$ century, the science of ecology established itself as a discipline concerned with ecological health and integrity, ecosystems, and natural equilibria. In the 1950-1960s, island biogeography, landscape and equilibrium ecology, and metapopulation dynamics emerged as biological subfields, positing the risk of extinction in relatively small, disconnected and isolated habitat spaces (Levins, 1969; MacArthur \& Wilson, 1967; Andrewartha \& Birch, 1954). Through the discipline of landscape ecology, concepts of matrix, mosaic, and corridors were introduced. Although still positivist in its outlook, landscape ecology moved from being a reductionist science to an integrative landscape approach (Arts et al., 2017).

By the late 1970s or the early 1980s, a number of influential publications raised alarm over the loss of biological diversity. Life on Earth was under threat according to Ehrlichs' Extinction in 1981, Myer's The Sinking Ark in 1979, and IUCN's World Conservation Strategy in 1980 (Dempsey, 2016). Propelled by such fears, conservation biology was consolidated as a 'crisis' discipline, 'concerned with the long-term viability of whole systems' (Soulé, 1985). These concerns widened conservationist attention from traditional legally protected areas (national parks and reserves) towards areas with ecological value regardless of their territoriallegal status, such as "ecosystems", "hotspots", "ecoregions", "bioregions", "biospheres" and "landscapes" (Redford et al., 2003; Myers, 1988; Risser, 1984; Sale, 1985; IUCN, 1978).

With the advancement of geospatial technologies and new concepts (e.g. ecosystem services), conservation planning and initiatives came to rely on science-based assessments in line with ecological principles as a way of analyzing, planning and doing conservation and development through concrete "landscape conservation" projects (Adams et al., 2014; Jongman et al., 2004). Landscape planners and managers have worked across institutional silos of academia, NGOs, donors, and government to overcome socially produced administrative, political or protected area boundaries to align conservation and development initiatives with perceived ecological boundaries and scales (Friess \& Jazeel, 2017; Zimmerer, 2006). Through the landscape approach, already established conservation initiatives were reconfigured in size and scope, from smaller-scale government-run spatially exclusive parks and reserves to less-exclusive schemes operated through private-public partnerships. Such schemes included the UNESCO's Biosphere program that was launched in the 1970s, integrated conservation and development projects that emerged in the 1980s, or transboundary/transfrontier conservation initiatives across nation-state borders that the International Union for 
Conservation of Nature (IUCN) began to promote in the 1990s $\mathrm{s}^{5}$. This shift to the landscape scale is reflected in IUCN's 2006 Connectivity Conservation Declaration, which emphasizes that the "maintenance and restoration of ecosystem integrity requires landscape-scale conservation" (Worboys et al., 2010, p.19).

Some of the key institutions that promote the landscape approach include the Centre of International Forestry Research (CIFOR), EcoAgriculture Partners, the Global Landscapes Forum (GLF), the FAO, the World Agroforestry Centre (ICRAF), the IUCN, Tropenbos International, the World Bank and the WWF (RosTonen et al., 2018). Several continental and global reviews of landscape initiatives have been conducted so far, underscoring the global phenomenon of the landscape approach to nature conservation: Estrada-Carmona et al. (2014) focusing on Latin America, Milder et al. (2014) on Africa, Denier et al. (2015) on the global South, García-Martín et al. (2016) on Europe, Reed et al. (2017) on the tropics, Zanzanaini et al. (2017) on South and Southeast Asia. In addition to these reviews, Worboys et al. (2010) offer a global overview of connectivity conservation initiatives and legislatures. Brooks et al. (2006) conclude that $79 \%$ of the global terrestrial area is under some form of regional prioritization for biodiversity conservation. ${ }^{6}$ The authors emphasize that the "scale of landscapes" matters to ensure the persistence of these different regions for biodiversity conservation. In short, the landscape approach has reached global significance.

So, what could be problematic about studying and intervening in nature-society relations through the landscape approach? In principle, there should be no objections to the idea of taking a comprehensive, holistic view on nature-society relations to address complex social-environmental problems. However, as suggested in the introduction, there are three intertwined problems worthy of consideration: depoliticization, simplification/decomplexification, and representation.

The first problem arises from the fact that scholars and practitioners who work with the landscape approach analytically, strategically, or both, privilege a positivist outlook in studying nature-society relations. This perspective tends to advance science-based claims to landscapes as spatial containers and totalities, instead of examining the question "Who owns, shapes and claims landscape?" (Friess \& Jazeel 2017, p. 15; also see Backhaus, 2011). This points to a well-rehearsed critique of scholarship and interventions that depoliticize conservation and development by rendering technical what are deeply political questions (Turnhout et al., 2020; Redford, 2011; Mansfield, 2009; Li, 2007; Mitchell, 2001; Ferguson, 1990). See for instance how Jianguo Wu, Professor of Landscape Ecology and Sustainability Science at Arizona State University and long-time editorin-chief of the journal Landscape Ecology sees the role of the landscape approach in "provid[ing] a common ground for ecologists, geographers, planners and designers, and policy-makers to work together to shape and improve the society-nature relationship" (Wu, 2012, p. 75). There is little space for marginalized voices, contested and irreconcilable visions about what constitutes desirable nature-society relations in such a scienceled framework of "enlightened specialists" and "expert observers" (Groening, 2007, p. 606; Wylie, 2007, p. 5).

The problem of depoliticization thus dovetails with the second problem, the question of what kind of knowledge practices promote the landscape approach? The main academic disciplines behind the landscape approach (sustainability sciences, conservation biology, landscape ecology, and some strands in geography) tend to take the landscape for granted as an already given and bounded space or scale with ecological, biogeographical, and cultural characteristics that become the basis for a positivist epistemology of landscape science, knowledge and expertise (Kühne et al., 2019; McCall, 2016; Wu, 2012; Redford, 2011). However, similar to the problem of anthropogenic climate change (Dunlap \& Brulle, 2015) and biodiversity loss (Evans, 2021), the object of analysis and intervention of the landscape approach are nature-society relations, not steady states of ecology and society, natural habitat and autonomous culture (Sheridan, 2009; Wylie, 2007). In other words, through the landscape approach, scientists and practitioners seek to revive a Sauerian concept of

\footnotetext{
${ }^{5}$ The first transboundary initiatives go back as early as 1930s in North America and Europe (Vasilijević et al., 2015), which were driven by the idea of establishing parks across international boundaries. The landscape framing did not appear implicitly until the 1970s, as the case of a Costa Rican initiative to protect "natural and cultural values" shows (Vasilijević et al., 2015, p. 4).

${ }^{6}$ These prioritizations are categorized as "crisis ecoregions", "biodiversity hot spots", "endemic bird areas", "centers of plant diversity", "megadiversity countries", "global ecoregions", "high-biodiversity wilderness areas", "frontier forests", and "last of the wild" areas.
} 
landscape that enables the empirical study of environmental change, which masks how social, ecological, economic and political relations are inscribed into space (Wylie, 2007).

What kind of science underpins a landscape approach to conservation is thus both an epistemological and political question. From post- and decolonial perspectives, we can push the critique further. Anthropologists of conservation, West et al. (2006, p. 265) highlight how through a positivist epistemology, conservation science decomplexifies nature-society relations, enabling scientists "to legislate the social relations between people and their surroundings." This leads the authors to conclude that "conservation, similar to colonialism, solidifies certain identities and ethnicities and incarcerates them in space and place" (p. 264). Indeed, this critique from anthropology resonates with some of the first critical studies of conservation initiatives through the landscape approach (Clay, 2019; Bluwstein, 2018; McCall, 2016; Clay, 2016). This critique also resonates with post-colonial scholarship in geography, which insists that scientific enframing and representation of nonEuropean socionatures as landscapes is "inherently colonizing" (Gregory, 2001, p. 93; also see Willems-Braun, 1997). Representation is an attempt to "superimpose a framework of meaning" (Mitchell, 1991) in order to make nature "available for inspection, codification, calculation, and regulation" (Gregory, 2001, p. 93). Landscape-based conservation science and practice is a prime example of such an attempt to determine what should be counted and accounted for as part of a landscape or not.

Following Derek Gregory's reconstruction of Edward Said's work on "imaginative geographies", a postcolonial critique of representation thus highlights how places and identities are "drawn into abstract grids of colonial and imperial power" and how they become "sites of appropriation, domination and contestation" (Gregory, 1995, p. 448). In short, the power of representation lies in claiming "empirical authority" and "colonial legitimacy" (p. 461). However, critique of representation may seem totalizing if there was no way out of representation. Is it not the role of science to represent? Here, Doreen Massey offers a way out by inviting us to embrace relationality as opposed to representation, when thinking about space (Massey, 2005). Importantly, relationality (between humans and humans, and humans and nonhumans) produces relations of responsibility and "a degree of interdependence that in many ways defies measurement" (Smith et al., 2007, p. 350; Setten, 2017).

Critical perspectives thus hold that nature-society relations cannot be represented - abstracted, enumerated, spatially mapped and modelled - with the tools of positivist landscape science without sacrificing complexity and dismissing more-than-human relationality and responsibility (Goldman, 2020; Sungusia et al., 2020; Setten, 2017; Moreno et al., 2015; Echeverri \& Román-Jitdutjaaño, 2013; Heckenberger, 2013; WillemsBraun, 1997). In the next section, I revisit the global history of landscapism to illustrate the colonial roots of simplification/decomplexification and representation.

\section{Revisiting the global history of landscapism}

\section{Colonizing landscapes}

Arts et al. (2017) trace the origins of the present landscape approach to Alexander von Humboldt's Kosmos (1834), thus at the time of colonial-scientific expeditions and modern state-making. Humboldt was indeed revolutionary in his attempt to formulate an integrative view on environmental change across different scientific disciplines (Grove, 1996). The European bourgeoisie embraced Humboldt's geographical idea of a totalizing concept of landscape because it needed a scientific theory of knowledge that purported to be politically neutral in order to legitimize its powerful role in modern society (Minca, 2007a). Following the political and scientific revolution in $18^{\text {th }}$ century Europe, landscape conceptions would transform a bourgeois nature aesthetic into a science of nature. This bourgeois science was a spatial science of the nascent modern state. It would become consolidated as an academic geography and it was instrumental in reducing place into (cartographic) space (Minca, 2007a; Minca 2007b). So much is clear, yet, we still need to understand where the idea of landscape came from, before it could be harnessed for political and scientific purposes.

Dennis Cosgrove is often cited when highlighting the roots of landscape thinking throughout Western Europe as an idea that emerged beginning with the fifteenth century and "came to denote the artistic and literary 
representation of the visible world, the scenery (literally that which is seen) which is viewed by a spectator" (Cosgrove, 1984, p. 9, emphasis in original). It was an elitist "way of seeing" the world that took centuries to become fully developed, eventually leading to landscape and nature becoming interchangeable categories by the end of the nineteenth century (Neumann, 1998). This way of seeing manifested in landscape paintings that were commissioned to legitimize bourgeois claims to property and authority, and thereby to exercise power over space (Cosgrove, 1985). These historical processes dovetailed with the construction and reproduction of class identities and divisions. The ability to appreciate and to consume aesthetic nature and landscapes came to be associated exclusively with the bourgeoisie (Neumann, 1998).

However, it was Kenneth Olwig who highlighted the lexicological origins, and more importantly, the political genealogy of landscapes before the notion of landscape became synonymous with scenery, before it become subject of appreciation for upper classes, before it was exported throughout the world through European colonialism, and before it entered the western academic canon. According to Olwig, the notion of landscape has developed in Europe long before landscape paintings emerged around the turn of the sixteenth century (Olwig, 2002). He faulted Cosgrove for associating landscape paintings with "scenery" only, as this diverts attention from "the politically charged connotations of landscape in the artistic and political discourse of the sixteenth century" (Olwig, 2002, p. xxv). ${ }^{7}$

Drawing on examples from northern Europe, Olwig is at pains in emphasizing how landscape paintings were not simply depicting scenery, but a polity's life in the countryside. ${ }^{8}$ Landscape was not defined in physicalgeographical but in social terms, signifying a polity governing itself under customary laws. The rural landscape/-schaft/-scab (as it was called in different Germanic languages) of northern Europe had its urban counterpart in citizenship (Bürgerschaft in German). Moreover, the "land" in "landscape" signified a connection of people with land, or territory. Landscape was in this sense "a polity's area of activity", a "political landscape" (Olwig, 2002, p. xxv), but also, as Raymond Williams put it, "a working country" (Williams, 1975, p. 120).

How did people come to associate themselves with landscape, or Landschaft? Here, Olwig highlights the defining political struggles in Renaissance Europe, in which divisions emerged between people and lords. People organized themselves as "corporate communities" (German Landschaften) in opposition to sovereign claims over land (and people) by the lords. These struggles between the lord and the landscape were mirrored in England in struggles between the court and the country (Olwig, 2002). To Olwig, these were essentially struggles over political representation, which led to the use of landscape paintings and cartography to depict a scenery to legitimize one's claims to property, authority, and territory. Whereas Italian landscape paintings sought to depict an idealized scenery of the rural pastoral devoid of human labor in line with principles of Roman natural law, artists in northern and central Europe mirrored customary laws of the land and labor in their paintings to represent place and polity (Olwig, 2002, p. 36ff).

Olwig's pathbreaking study shows how in the wake of European processes of modern state formation and nation building, territorial sovereignty was increasingly consolidated over larger areas by appropriating rural landscapes (autonomous political communities) and their labor. New pictorial and cartographic representations of the sovereign's territory were produced through paintings, surveys and maps in order to display the new possessions and to stake claims of ownership, control and legitimacy. Landscape paintings "conflated the nation, as a people, with the landscape identity of a geographic body, thereby facilitating this envisioning of the nation as a unity of physical nature and people" (Olwig, 2002, p. xxx). Landscapes as pictorial representations can thus be understood as "dreamwork", projected onto spaces and communities who live on and off the land and its resources, and who through their labor shape their surroundings as "groundwork" (Mitchell, 2003, p. 787). This is echoed well by Jeff Malpas who associates the power to represent through landscape art with the 'dark side' of landscape:

\footnotetext{
${ }^{7}$ Echoing this European history, Berr \& Schenk (2019) provide a review of the German body of literature on the genealogy of landscape. Also, see a non-Eurocentric account of early notions of landscape outside of Europe, such as in China (Berque, 2013) and Nigeria (Okoye, 2016).

${ }^{8}$ See for instance, Peter Bruegel's 1565 painting The Harvesters.
} 
The 'representational' character of landscape as an art form is often taken to underpin the 'dark side' of landscape-its complicity in exclusion and oppression - since it is precisely in and through the representational character of landscape art that landscape art is seen as constructing the landscape that it presents in ways that reinforce the relations of power and authority that hold sway within it (Malpas, 2011, p. 6).

Thus, despite their differences, Olwig and Cosgrove meet at an important point. Olwig highlights how through commissioned landscape paintings differences and struggles were masked as a natural landscape scenery under "'the natural' laws of the monarch" (Olwig, 2002, p. xxx). Such landscape paintings - pioneered in Renaissance Italy (Cosgrove, 1985) - illustrated an "illusion of an idyllic" countryside (Olwig, 2002, p. xxxi; Groening, 2007). The countryside was landscaped through surveys and maps, which solidified claims to land while extinguishing local customary rights to the same (Olwig, 2002, p. 119). "Land" and "place" became associated with "property" (Olwig, 2002, p. 123) and "Nature" with "Nation" (Olwig, 2008, p. 75; Minca, 2007a). Over the course of several centuries, landscapes came to be reconfigured from being understood as political communities knitted by custom to being associated with (natural) scenery devoid of labor, poverty, and social injustice (Groening, 2007; Neumann, 1998). Olwig describes how this transformation remained incomplete throughout Europe, but was most successful in England. The once political landscapes defined by culture, labor and custom came to be seen as physical landscapes upon which sovereign power could be exercised through material and symbolic appropriation. Cosgrove's reconstruction of the landscape concept as a way of seeing is not at odds with this analysis. Cosgrove recognized the appropriation of commons into state and private property (enclosures) as a central function of the landscape way of seeing, next to the ideological function of landscape images as ways to reproduce elitist values and norms (Cosgrove, 1985).

Geographers conceptualize these historical processes of enclosure and appropriation of land, labor and resources as acts of territorialization (Vandergeest \& Peluso, 1995; Sack, 1986). The analytics of territorialization includes processes of territorialization and re-/counter-territorialization, power exercises that can be harnessed by anyone who seeks to stake claims to land, people, labor and resources, and can legitimize these claims. Conceptually, territorialization thus does not fully capture what was at stake when autonomous political communities (landscapes) were appropriated as spaces of territorial sovereignty in European processes of state formation and nation building. Whereas these communities could have tried - successfully or not - to regain some degree of autonomy through acts of counter-territorialization, the lands that they occupied were once and for all symbolically enframed and reconfigured into landscapes filled with "objects" and "things", spatial containers to denote power and territory of the new sovereign, the modern state (Minca, 2007a).

Thus, from the vantage point of post- and decolonial studies, it makes sense analytically to see the history of territorialization of autonomous political communities (landscapes) as a history of internal colonization. ${ }^{9}$ The concept of internal colonization posits that colonial practices do not have a particular beginning and end point, nor are these practices limited geographically to regions outside of Europe. Pinderhughes (2011, p. 236) offers a broad but still specific definition of internal colonialism "as a geographically-based pattern of subordination of a differentiated population, located within the dominant power or country" (emphasis in original). Importantly, Turner (2018, p. 770-771) adds that the "process of internal colonization is based on a coloniality of power and epistemic violence." It is the reference to epistemic violence (see Spivak, 1988) that highlights how the power to colonize is underpinned by a logic of representation. Seen this way, landscape paintings and maps were devices of representation that were used to territorialize and to colonize political communities. Cosgrove's elitist gaze that underpinned a landscape way of seeing was also a "colonial gaze" (Eeden, 2004).

\footnotetext{
${ }^{9}$ The concept was initially proposed by scholars of Latin America and of the US South, and has been applied in other contexts as well. See for instance Calvert (2001) on internal colonization of the US South, Etkind (2011) on Russia's imperialism and internal colonialism, Fernandez-Armesto and Muldoon (2017) on internal colonization in medieval Europe, Healy and Dal Lago (2014) on the historical relationship between colonialism and nation states within Europe (including the familiar and emblematic case studies of Ireland, Southern Italy and Eastern Europe), van de Grift (2015) on internal colonization within interwar Europe, Turner (2018) on internal colonization in the making of the British state (in the past) and its ramifications in the age of War on Terror within Britain (in the present).
} 
Ultimately, then, the contemporary notion of landscape as a spatial container was made possible through a violent history of colonizing landscapes in Europe. Today, this history is largely forgotten (Minca, 2007a; Olwig, 2002), in part because the process of colonizing landscapes has been complete. With exceptions, Europe's history of state formation and nation-building has been settled. Ideas about what cultural landscapes should look like are deeply entrenched and hegemonic. This is not to suggest that there are no struggles in Europe over what cultural landscapes should look like (Kühne et al., 2019; Groening, 2007). Yet, in post-war Europe, the stakes are relatively low compared to regions where the idea of landscape continues to have the power to advance political inclusion and exclusion. In the remainder of this section, I revisit the history of landscapism outside of Europe.

\section{Landscaping colonies}

The history of European expansion through colonialism represents the other important part of a global history of landscapism. By the time European powers colonized the world, British landscape gardens had spread throughout Europe and the discourse of landscape as (natural) scenery and a spatial container was firmly established in science and (high) society. European landscape projections inspired the global park movement (that started in the North American settler-colony) and shored up ideological, racialized, classed and nationalist responses (Lekan \& Zeller, 2014; Olwig, 2002). Colonized territories were at once scientifically "misread" (Fairhead \& Leach, 1996) and landscaped (materially and symbolically) by European powers and settlers who projected and sought to recreate familiar landscapes of their homelands in new environments (Braverman, 2019; Moon, 2018; Malpas, 2011; Ford, 2008; Groening, 2007; Sunderland, 2004; Adams, 2003; Plumwood, 2003; Sluyter, 2001). Colonization was underpinned by the "myth of emptiness", a way of seeing unfamiliar spaces of human-nonhuman co-existence as un(der)populated, unproductive, wild landscapes or barren wastelands (Plumwood, 2003; Sluyter, 2001). Another important driver was the Orientalist search for Edenic, ancient biblical, natural, timeless and pristine landscapes in the colonies, which dovetailed with Cartesian epistemologies of nature and culture (Braverman, 2019; Davis \& Burke, 2011; Malpas, 2011; Adams, 2003; Smith, 1999; Sundberg, 1998; Grove 1996; Fairhead \& Leach, 1996; Willems-Braun, 1997; Adams \& McShane, 1992; Said, 1979).

Environmental historian Richard Grove highlighted the global extent of these symbolic and material practices that I call landscaping colonies. The following paragraph from Grove (1996) deserves to be quoted at length:

During the fifteenth century the task of locating Eden and re-evaluating nature had already begun to be served by the appropriation of the newly discovered and colonised tropical islands as paradises. [..] These imaginative projections were, not, however, easily confined. Conceptually, they soon expanded beyond the physical limitations of the botanical garden to encompass large tropical islands. Subsequently the colonialist encounter in India, Africa and the Americas with large 'wild' landscapes apparently little altered by man, along with their huge variety of plants [..], meant that the whole tropical world became vulnerable to colonisation by an ever-expanding and ambitious imaginative symbolism. Frequently such notions were closely allied to the stereotyping of luckless indigenous people as 'noble savages'. Ultimately, then, the area of the new and far more complex European 'Eden' of the late eighteenth and early nineteenth century knew no real bounds. Even Australia and Antarctica, in recent years, have not been immune to being termed Edens (Grove, 1996, p. 5, my italics)

Grove's global environmental history of how western landscape ideas and projections came to underpin colonization remains descriptive, but echoes Linda Tuhivai Smith' decolonial critique of this symbolism and its effects. As a scholar of indigenous studies and decolonization, Smith (1999) points out how these colonizing 
practices hinge on the power to represent peoples and their relationships to land and environment, and people's perceptions of themselves: ${ }^{10}$

For the indigenous world, Western conceptions of space, of arrangements and display, of the relationship between people and the landscape, of culture as an object of study, have meant that not only has the indigenous world been represented in particular ways back to the West, but the indigenous world view, the land and the people, have been radically transformed in the spatial image of the West. In other words, indigenous space has been colonized. [..] Renaming the land was probably as powerful ideologically as changing the land. [..] More significantly, however, spaces were appropriated from indigenous cultures and then 'gifted back' as reservations, reserved pockets of land for indigenous people who once possessed all of it. (Smith, 1999, p. 51, my italics)

By now it should hopefully be clear how the period that I called colonizing landscapes in Europe prefigured the period landscaping colonies outside of Europe. Rod Neumann offers an insightful study of this double movement through attention to struggles over rural livelihoods and nature preservation in Northern Tanzania (Neumann, 1998). In a historical, geographical and political ecological account spanning Europe and East Africa, Neumann draws on Cosgrove's analysis of a landscape way of seeing to highlight the European roots of a picturesque, scenic African landscape vision that was imposed on peasants and pastoralists, thereby ignoring historical struggles over land and resources. Neumann skillfully connects struggles over land and resources in colonial and postcolonial Tanzania with much older struggles in Europe over the question of what constitutes nature and landscape.

The global history of landscapism - colonizing landscapes/landscaping colonies - thus highlights struggles over state formation and nation building, sovereignty and representation, property and authority, land and territory, landscape and nature. This history cannot be put to rest as long as contemporary invocations of landscape continue to draw on it - if only unintentionally - to legitimize particular ideas about people and nature (Groening, 2007). To be sure, the trouble with landscapism in conservation is contingent on the degree of inclusiveness and exclusiveness - political and ethical enfranchisement - that humans and nonhumans enjoy in particular places. Are landscapes associated with peopled spaces or with spaces threatened by people? Are landscapes understood as embodiments of fluid nature-society relations inscribed in the land, or as spatial containers with fixed and essential natural and cultural properties? Here, the stakes go beyond a division into 'inclusive peopled and cultural' versus 'exclusive peopleless natural landscapes.' We also need to pay attention to the cultural politics of landscape belonging (see Toomey, 2020; Willems-Braun, 1997). Do cultural landscape narratives and imaginaries promote a purist, static, exclusive idea of culture in order to privilege some groups over others, or to promote conservation in the name of an essentialized cultural image (Ramutsindela, 2016)? How is inclusion/exclusion racialized, ethnicized, indigenized or hierarchized in other ways (Mollet \& Kepe, 2018)? And ultimately, from the vantage point of decolonisation, who is doing the representing of these places as landscapes (Todd, 2016), how are they represented, and are there ways around representation in nature conservation? To give a brief insight into some of these questions, the next section zooms in on a Tanzanian landscape initiative that I have studied for some years.

\section{Landscaping Africa: the case of a contemporary landscape conservation initiative in Tanzania}

In some senses, a park in savannah Africa could hardly ever be big enough. An ecosystem in North America or elsewhere in the temperate zones is generally not as complex nor as integrated as those in savannah Africa (Myers, 1972, p. 1257).

${ }^{10}$ Also see Mbembe (2015) and Willems-Braun (1997) 
Unlike in regions where concerns with the disappearance of landscapes as cultural heritage prevail (most prominently in Europe), contemporary African landscape conservation initiatives tend to associate landscapes with natural, timeless spaces threatened by growing human activities. Although it is debatable if the concept of landscape is an appropriate term to make sense of African spaces (see edited volume in Beardsley, 2016), there is a consensus that a colonial way of seeing and representing an exclusive, natural landscape was imposed on the African continent despite an extensive human presence and a deep cultural history (Beardsley, 2016; Sheridan, 2009; Eeden, 2004; Adams \& Mulligan, 2003; Guyer \& Richards, 1996). This way of seeing and representing African peoples and spaces was underpinned by Malthusian, essentialist, and romantic images of an Edenic landscape untouched by human civilization (Ramutsindela, 2016; Davis and Burke, 2011; Neumann, 1998; Guyer \& Richards, 1996; Adams \& McShane, 1992; Anderson \& Grove, 1988).

See, for instance, how UNESCO classified the Cévennes region in France as a World Heritage Site in 2011, seeing an ancient "agro-pastoral cultural landscape" worthy of protection. ${ }^{11}$ Now compare with how UNESCO placed the Simien Park in Ethiopia on the list of World Heritage in Danger in 1996 (having recognised it as a Heritage Site in 1978) because it perceived the park's human residents as a threat to the landscape (Blanc, 2016). In France, UNESCO is at pains in emphasising the "wholeness or intactness of the cultural landscape", whose "traditional activities" must be maintained, supported and revived ${ }^{12}$, but in Ethiopia the same institution sees a "spectacular landscape" in need of protection from anthropogenic forces. ${ }^{13}$ To be sure, as in France, human residents of the Ethiopian World Heritage Site are acknowledged to have lived in the area prior to its recognition by UNESCO. However, unlike in France, humans are not celebrated as part of the landscape, but as a threat to it. To UNESCO, the Ethiopian park's "integrity" is threatened by "human settlement, cultivation and soil erosion", "frequent fires" and "excessive numbers of domestic stock". ${ }^{14}$ While the stakes are significantly higher for rural people in Ethiopia (who are facing the risk of dispossession or eviction) than in France (who are expected to remain "traditional"), the similarities across both cases lie in the way in which UNESCO assumes a landscape way of seeing, to project an idea of what a landscape should look like. In this sense, landscapism is a deeply conservative project (Groening, 2007). What is more, UNESCO's heritage program in Africa illustrates landscapism's enduring colonial legacy (Noe, 2019).

International NGOs and their donors promote large-scale conservation and development initiatives today, continuing to legitimize colonial visions of what Africa ought to look like (Brockington \& Scholfield, 2010). Since the 1990s, colonial visions of a landscaped Africa as a borderless space culminated in the proliferation of transboundary/ transfrontier conservation initiatives across nation state borders, spearheaded in Southern Africa by the NGO Peace Park Foundation (Ramutsindela, 2017; Noe, 2010; Wolmer, 2003). The underlying motivation to transcend state borders in order to "re-naturalize" African landscapes to a pre-colonial state reveals the dominant vision of a continent whose people and their histories tend to be erased in western imagination (Ramutsindela, 2016). Yet, given the deeply interventionist and often coercive nature in which landscape-based conservation initiatives are introduced on the continent, landscaping Africa has led to more, not less, bordering when older state-led protected areas were reconfigured into large-scale NGO- and donordriven landscape initiatives (Noe, 2014; Ramutsindela, 2007). These initiatives can include up to several million residents and are primarily motivated by the conservation biodiversity and natural resources (Milder et al., 2014). Looking at the territorial extent of landscape initiatives on the continent, one could be inclined to equate their geography with a neocolonial scramble for Africa. ${ }^{15}$

\footnotetext{
${ }^{11}$ https://whc.unesco.org/en/list/1153

12 https://whc.unesco.org/en/list/1153

13 https://whc.unesco.org/en/list/9

${ }^{14}$ https://whc.unesco.org/en/list/9

15 Back in 1988, David Anderson and Richard Grove referred to "the Scramble for Eden" through African conservation (Anderson \& Grove, 1988), while Rod Neumann suggested that the rise of big international conservation NGOs in the second half of the 20th century constitutes "the second Scramble for Africa" (Neumann, 2002, p.37). South African geographer Maano Ramutsindela sees an "imperialist vision for a continent-wide connectivity" at work through transfrontier conservation initiatives in Africa today (Ramutsindela, 2007, p. 136). Tanzanian geographer Christine Noe sees present conservation initiatives advanced by international conservation NGOs as economic vehicles to grant different actors access to land and mineral resources in a neocolonial scramble for the continent (Noe, 2019, p.2).
} 
Rural livelihoods are key objects of analysis and intervention in landscape conservation scholarship and initiatives on the African continent today. The goal is to make rural livelihoods compatible with conservation goals and essential landscape visions, echoing colonial projects of improvement (McCubbin \& Hovorka, 2020; Bluwstein, 2018; Davis \& Burke, 2011). Improvements are often understood as income diversification schemes such that rural people become less dependent on land and land-based resources (Milder et al., 2014). In many cases, such initiatives operate in the absence of economic alternatives and formal job markets (Ferguson, 2015). In seeking to arrest land-based economic development such as cultivation or extensive livestock keeping, livelihoods of land-dependent farmers and pastoralists living in conservation landscapes are problematized as being at odds with ecological principles that privilege connectivity of wildlife habitats across different land categories and uses (Bluwstein et al., 2018).

The three problems that I associate with the landscape approach to conservation are thrown into sharp relief here. First, by drawing on positivist epistemologies, landscape conservation initiatives depoliticize environmental protection into a set of technical interventions driven by experts. Questions of land and resource access and control - how power relations underpin nature-society relations in time and space - are elided and the stakes for people who are subjected to these interventions are ignored or obscured. Second, these technical interventions are based on a set of ecological concepts and indicators that ought to enable the quantification of the ecological state of the landscape. To improve the ecological state, landscape conservation initiatives promote the proliferation of different land use categories, borders, and land and resource use regimes to reconfigure and reorder how humans and nonhumans should share space and co-exist in the landscape. Put differently, nature-society relations are epistemologically simplified/decomplexified and materially reconfigured to align them with a landscape vision that is ecologically undisturbed by humans. Third, all of this requires that someone is doing the work of representing African rural spaces as conservation landscapes their scientific framing and scripting as spatial containers with valuable nature and biodiversity, threatened by human "disturbance." It is here that the role of conservation scientists and NGOs as landscape architects - often complicit with the state - comes to the fore.

A recent study is a case in point. Assessing a continent-wide elephant population across 73 protected areas, Robson et al. (2017, p. 1) produced an "ecological benchmark" for African elephants by modelling "primary productivity, water availability, and an index of poaching as predictors." Humans were only included in the model as poaching threats to the elephant habitat that otherwise should yield an "environmentally mediated equilibrium level" (Robson et al., 2017, p. 2). With the exception of seeing Africans-as-poachers, humans and human-animal (domestic and wild) relations were thus not considered as part of the environment. Moreover, no considerations were given as to how many of the 73 protected areas may have been carved out of previously human-dominated territories, which would have upset underlying assumptions about natural carrying capacities of these spaces. Eventually, the model calculated a hypothetical "ecological benchmark" of an elephant population under zero poaching conditions, suggesting that present populations across the 73 protected areas represent around $25 \%$ of its full potential (under "natural conditions"), corresponding to a deficit of 730,000 animals.

In this sense, a seemingly natural habitat was conjured up through the confluence of scientific practices of simplification/decomplexification and representation of nature-society relations as elephant landscapes threatened by humans. ${ }^{16}$ Yet, for two reasons, it would be a mistake to suggest that the modellers were simply misrepresenting African landscapes by applying problematic - Malthusian - assumptions. First, a colonial gaze of representing other people and places cannot be corrected through a better, more accurate representation (Mitchell, 1991). From a decolonial perspective, the opposite of representation is not misrepresentation, but the refusal to represent. There is no "true" way to represent - scientifically or otherwise - how people should live with elephants. But we could ask people how they want to live with wild animals and if there are ways to make people-animal co-existence more accommodating for the needs of all. Second, a scientific model as produced by Robson et al. (2017) would be unthinkable in, say, central Europe, where the idea that humans are primary threats to "natural" environments is an absurd idea to conservationists working with the landscape approach.

\footnotetext{
${ }^{16}$ Also see McCubbin and Hovorka (2020) for a critical analysis of how African rural poor are similarly understood as primary, if not exclusive, threats to African lionscapes in conservationist imaginaries of the continent.
} 
However, it is not absurd because it is scientifically untenable. It is an absurd idea because centuries of seeing central Europe as a cultural landscape and Africa as a natural landscape have overdetermined what scientific questions are rendered relevant and what scientific truths are pursued.

My own research draws on a conservation landscape initiative - Tarangire-Manyara Ecosystem - which was included in the model produced by Robson et al. (2017). According to the model, Tarangire National Park in Northern Tanzania should have an ecological benchmark density of around 3.25-3.75 elephants $/ \mathrm{km}^{2}$ under zero poaching conditions (amounting to roughly 10,000 animals). The model thus implies that the park, with its current density of around 1.2 elephants $/ \mathrm{km}^{2}$ (as of 2015), is significantly underpopulated due to adverse human activities. However, given that elephant poaching is not an issue in Tarangire, the model also implies that mere human presence around the park is responsible for a substantial elephant population deficit. Indeed, several hundred thousand people live around the park in a perimeter of elephant movements (Figure 1). People and elephants share a semi-arid environment far beyond the borders of the park. Hence, people living with wildlife around Tarangire National Park and even many, if not most, park managers would find a threefold increase in elephant numbers unthinkable and undesirable, given that people-elephant relations have been significantly strained in the region due to regular crop raids and human lives lost to elephants (Bluwstein, 2018).

In what follows, I illustrate how Tarangire was actively landscaped (symbolically and materially) to become a natural ecosystem for wildlife threatened by human presence. My intention is not to single out a particular, unique place, but to highlight historical developments that are representative of similar processes far beyond the region, Tanzania, or even East Africa. By highlighting the process of landscaping, I invite the reader to assume a decolonial perspective on nature-society relations by refusing to take for granted that Tarangire is part of a conservation landscape.

\section{Landscaping Tarangire, becoming an ecosystem}

Tarangire-Manyara Ecosystem (TME) is a label for an NGO- and donor-driven landscape conservation initiative that spans three state-managed protected areas (two national parks - Tarangire and Lake Manyara, one game reserve - Mkungunero), and several community-based conservation initiatives on village land, known as Wildlife Management Areas, or WMAs (Bluwstein, 2018). The initiative is spatialized around Tarangire River which supplies wildlife with water inside Tarangire National Park during the dry season. During the wet season, wildlife leaves the park boundaries and moves across TME, a mosaic of protected areas and agropastoral land use. TME conservation scientists and managers apply the landscape approach in order to match conservation analysis and intervention with the full wildlife habitat of the ecosystem as they perceive it.

Beginning in the 1930s and into the 1950s, colonial administrators were torn between seeing the area around Tarangire River as either a largely people-less space that should become a wildlife refuge, or as a humandominated agricultural space (Årlin, 2011). These two different imaginative geographies reflected colonial visions of Africa at the time. Echoing an entrenched nature-culture dualism, colonial administrators believed that the interests of rural livelihoods and wildlife could not be reconciled and had to be separated territorially. This way of seeing nature-society relations ignored a history of local co-existence of people and wildlife, and local practices of wildlife population control. After years of deliberation and negotiation, Tarangire was officially established as a Game Reserve in 1957 to separate rural communities from wildlife, although people retained access to the reserve to some degree. Wildlife was to be confined inside the reserve, encouraging tourist hunting within, and agricultural land use around it (Bluwstein, 2018).

Since the 1960s, conservationists have followed wildlife movements in the area to map the spatial and temporal extent of wildlife habitats. They quickly realised that wildlife's territorial footprint goes far beyond the boundaries of the Tarangire Game Reserve. In the 1980s, growing scientific evidence of wildlife movements across the park boundaries ${ }^{17}$ converged with the rise of the landscape approach to conservation. A new way of seeing people, animals and the environment became hegemonic. Rather than seeing a protected area primarily as a container for wildlife and tourist hunting, Tarangire came to represent a much larger conservation landscape

\footnotetext{
${ }^{17}$ The Game Reserve was upgraded to a National Park in 1970, see "Tarangire NP" in Figure 1. With this upgrade, rural people living around the park lost their access to land and resources within Tarangire.
} 
of endangered wildlife amidst treacherous rural spaces (Bluwstein, 2018). The national park became landscaped into a larger ecosystem threatened by humans.

Ever since, rural livelihoods and environments around Tarangire have been represented through a dominant landscape vision of international nature conservation that privileges a Malthusian, essentialist idea of a timeless, wild Africa which is at once threatened by residents and open for global tourism. One international NGO was particularly successful in representing Tarangire as a conservation landscape of global conservation and tourism value. In 1989 the Washington DC based African Wildlife Foundation (AWF) joined the global ivory trade ban campaign in the wake of widespread African elephant poaching in the 1980s. This helped raise its profile, with substantial funding from USAID. In the 1990s, AWF created a branding campaign to further attract North American funding by framing African environments as AWF Heartlands (Sachedina, 2008). Tarangire became the centre of AWF's Maasai-Steppe Heartland, a synonym for Tarangire-Manyara Ecosystem and one of AWF's signature landscape conservation initiatives (Figure 1). AWF framed its approach as "threatsbased conservation at a landscape scale" and identified "subsistence agriculture, unplanned settlements, and inadequate land use" as the main threats to the "the ecological viability of landscapes" (Bluwstein, 2018, p. 160, quoting from AWF brochures).

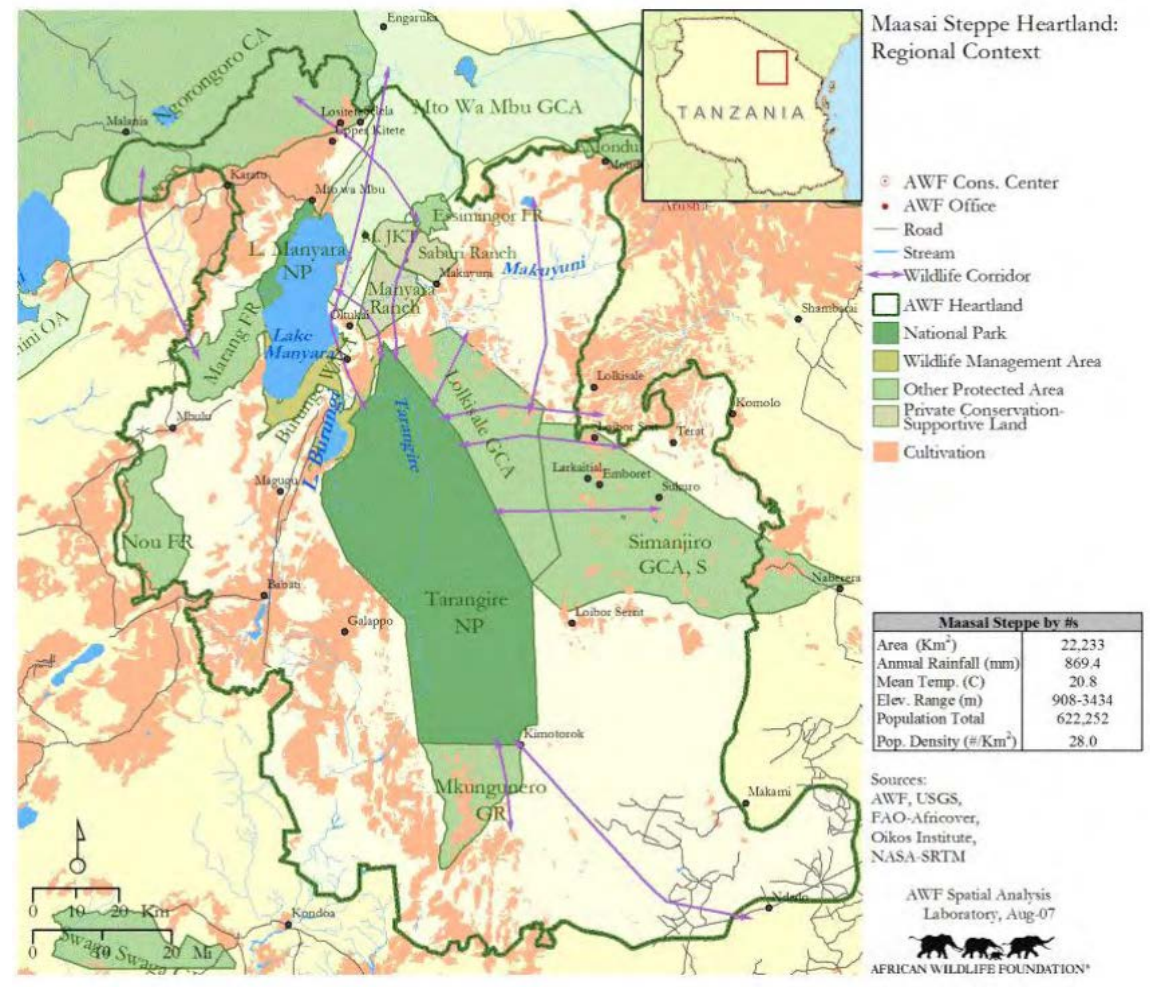

Figure 1: Tarangire-Manyara Ecosystem, also known as AWF's Maasai Steppe Heartland. Source: Sachedina (2008).

In the context of landscape conservation, the presence of humans around Tarangire was framed as ecologically invasive to the area; an ecological impurity that had to be managed. AWF's landscape vision was based on top-down ecological planning which ignored local ecological knowledge and decomplexified socioecological environments into manageable units (Goldman, 2003; Goldman 2020). Two scientific concepts played a particularly important role in representing the area as a wildlife landscape in need of conservation - 
wildlife corridors and wildlife censuses. Wildlife corridors became an important ecological tool to conceptualize and ensure wildlife movements amidst rural territories, despite a great deal of conceptual and epistemological uncertainty as to what constitutes a corridor (Goldman, 2009; Wyborn, 2015). ${ }^{18}$ To Maasai pastoralists it made little sense to think of their villages in terms of corridor-based wildlife movements. To them, wildlife, livestock, homesteads and people share the space together (Goldman, 2020). Wildlife censuses became a key proxy for conservation biologists in studying the ecological state of TME. While repeated wildlife censuses have ensured sustained research funding and provide a sense of scientific robustness and representativeness, they neglect other ecological questions and concerns, such as the capacity of the environment to sustain complex human-nonhuman assemblages (Brockington, 2002; Brehony et al., 2017). Seeing Tarangire as a conservation landscape thus fostered a simplified and narrow view of nature-society relations.

Under this ecologically impoverished and exclusive landscape vision, state and park forces conducted evictions and resettlements throughout different parts of TME to establish, clear and secure spaces for wildlife corridors (Bluwstein, 2018; Sachedina, 2011; Sachedina, 2008; Igoe \& Croucher, 2007). AWF worked with images of a spectacular nature to promote its initiative as a conservation landscape for a global audience of prospective tourists, donors, transnational policy events and green consumerism (Igoe, 2017). As elsewhere (Minca, 2007b), the idea that Tarangire is a landscape has played an important role in constructing colonial tourist imaginaries about and encounters with people and wildlife (Bluwstein, 2017). An ecotourism company not associated with AWF explicitly drew on this landscape vision and combined it with the idea that the landscape is held together ecologically by an ancient wildlife corridor connecting Tarangire and Lake Manyara National Parks. ${ }^{19}$ To recover the corridor from human disturbance, village land used for livestock grazing was appropriated for exclusive ecotourism (Bluwstein, 2017). Drawing on the idea of ancient wildlife corridors, state conservation authorities similarly tried to enrol an extensively farmed, grazed and settled area south of Tarangire - the largely wildlife-free Mkungunero Game Reserve - into the landscape vision of TME (Bluwstein, 2019). Both cases have led to land and resource conflicts that are still unresolved.

Representing and territorializing the area as a landscape was met with varying degrees of local resistance, but also with strategic acceptance. Throughout the 1980s and 1990s Maasai residents east of the park resisted the repeated efforts to landscape their environments for conservation (Igoe and Brockington 1999, Sachedina 2008). In the 2000s, residents living west and southeast of Tarangire have resisted numerous attempts by government authorities to impose a tourism-based conservation regime on their livelihoods (Bluwstein, 2019; Bluwstein, 2018; Bluwstein, 2017; Igoe \& Croucher, 2007). Yet, some local groups lent their support to police their environments against unwanted land use activities in line with a conservationist landscape vision. In the 1990s, Maasai communities northeast of Tarangire National Park collaborated with private safari tourism companies to host tourism on village lands. ${ }^{20}$ In exchange, they would receive revenues, and their land would be safeguarded against the risk of land alienation by large-scale agricultural development or the expansion of Tarangire National Park onto village land (Bluwstein, 2018; Sachedina \& Nelson, 2010). The above-mentioned example of ecotourism west of Tarangire National Park (in Burunge Wildlife Management Area, Figure 1) exploited intra-village politics to evict an ethnic minority of Barabaig pastoralists with support of local district and village government (Bluwstein, 2017). Within the scope of the conservation initiative called Makame Wildlife Management Area, Maasai pastoralists living southeast of Tarangire embraced a REDD+ project as an opportunity to maintain land control vis-à-vis in-migrating non-Maasai farmers in search for arable land (Bluwstein, 2019). ${ }^{21}$

As these different examples illustrate, the landscape vision of Tarangire fed into local land politics of inclusion and exclusion, underpinned by ethnic differences and economic interests. Whereas some agro-

\footnotetext{
${ }^{18}$ See Figure 1 for how AWF and conservation scientists envision wildlife corridors in the conservation landscape around Tarangire.

${ }^{19}$ See Burunge Wildlife Management Area in Figure 1.

${ }^{20}$ See Lolkisale and Simanjiro GCA in Figure 1.

${ }^{21}$ Makame Wildlife Management Area, not shown in Figure 1, but its location overlaps with the wildlife corridor southeast of Tarangire.
} 
pastoralists were asked not to expand their agricultural activities in order to be tolerated in the landscape, other agro-pastoralists were framed as invaders to make space for ecotourism that draws on the exclusive landscape vision. By and large, farmers and landless people in search for land were stigmatized as a threat to the landscape, living at risk of being evicted (Bluwstein, 2018).

\section{Conclusion: decolonizing landscapes?}

The point of this article is not to question nature conservation per se, but to highlight its colonial legacies in the present. As the case of Tarangire has illustrated, the very framing of a landscape - regardless if it is for analytical or for strategic purposes - can produce spaces of inclusion and exclusion. Such spaces may not be advanced in the name of the nation any longer (as the process of colonizing landscapes has shown), yet nature as the successor of nation in the struggle over land and territory can give rise to processes that I call landscaping colonies (see Lowenthal, 2007).

So what could decolonizing landscapes look like? Should we re-appropriate the landscape concept or should we do away with the concept altogether? Friess and Jazeel (2017) call for a third option - the provincialization of the landscape concept and its "unlearning" as a spatial descriptor. Don Mitchell's challenge to go beyond "the fetishized landscape as our starting point" remains relevant (Mitchell, 2003, p. 790). Following Tim Mitchell, a decolonial perspective on landscapes and conservation has also to disavow "the metaphysic of representation" (Mitchell, 1991, p. xvi). Instead of representation, conservation has to start with acknowledging relationality (Goldman, 2020; Toomey, 2020). Here, phenomenological approaches to landscape as more-than-human embodiment, inhabitation, dwelling, and belonging may help counter a landscape way of seeing nature-society relations as spatialized containers (Wylie, 2007). At the very least, decolonizing landscapes is akin to refraining from understanding landscapes as visual sceneries, spatial containers, abstract ecologies, or static, autonomous cultural spaces. Instead, we need to conceptualize landscapes as places and polities imbued with politics, power and (in)justice (Olwig \& Mitchell, 2007). In this vein, this article argues for a critical re-appropriation of the notion of landscape in conservation and environmental science, policy and practice, away from its technical and instrumental, scientific-positivist use. And ultimately, if decolonization should not remain a metaphor (Tuck and Yang 2012), decolonizing landscapes in settler- and post-colonial conservation contexts must be based on giving land back to people, whose historic dispossession has been entangled with the making of conservation landscapes.

\section{References}

Adams, J. S., \& McShane, T. O. (1992). The myth of wild Africa: conservation without illusion. University of California Press.

Adams, W. M. (2003). Nature and the colonial mind. In Adams, W. M. \& Mulligan, M. (eds), Decolonizing nature: strategies for conservation in a post-colonial era. (pp. 16-50). Earthscan.

Adams, W. M., Hodge, I. D., \& Sandbrook, L. (2014). New spaces for nature: the re-territorialisation of biodiversity conservation under neoliberalism in the UK. Transactions of the Institute of British Geographers, 39(4), 574-588. https://doi.org/10.1111/tran.12050

Adams, W. M., \& Mulligan, M. (2003). Decolonizing nature: Strategies for conservation in a post-colonial era: Earthscan.

Amo-Agyemang, C. (2021) Unmasking resilience as governmentality: Towards an Afrocentric epistemology. International Politics. https://doi.org/10.1057/s41311-021-00282-8

Anderson, D., \& Grove, R. H. (1988). Conservation in Africa: Peoples, policies and practice. Cambridge University Press.

Andrewartha, H., \& Birch, L. (1954). The distribution and abundance of animals. University of Chicago Press.

Årlin, C. (2011). Becoming wilderness. A topological study of Tarangire, Northern Tanzania, 1890-2000. (PhD thesis), Stockholm University, Stockholm.

Arts, B., Buizer, M., Horlings, L., Ingram, V., van Oosten, C., \& Opdam, P. (2017). Landscape approaches: a state-of-the-art review. Annual Review of Environment and Resources, 42, 439-463. https://doi.org/10.1146/annurev-environ-102016-060932 
Backhaus, N. (2011). Landscapes, spatial totalities or special regions? Procedia - Social and Behavioral Sciences, 14, 193-202. https://doi.org/10.1016/j.sbspro.2011.03.036

Beardsley, J., ed. (2016). Cultural landscape heritage in Sub-Saharan Africa. Dumbarton Oaks Research Library and Collection. Washington D.C.

Berr, K., \& Schenk, W. (2019). Begriffsgeschichte. In Kühne, O., Kinder, S. \& Schnur, O. (eds) Handbuch Landschaft. (pp. 23-38). Springer VS.

Berque, A. (2013). Thinking through landscape. Routledge.

Blanc, G. (2016). Violence et incohérence en milieu naturel: une histoire du parc éthiopien du Semēn. Études rurales, 197, 147-170. https://doi.org/10.4000/etudesrurales.10691

Blomley, N. (1998). Landscapes of property. Law \& Society Review, 32(3), 567-612.

Bluwstein, J. (2017). Creating ecotourism territories: Environmentalities in Tanzania's community-based conservation. Geoforum, 83, 101-113. https://isiarticles.com/bundles/Article/pre/pdf/94270.pdf

Bluwstein, J. (2018). From colonial fortresses to neoliberal landscapes in Northern Tanzania: a biopolitical ecology of wildlife conservation. Journal of Political Ecology, 25, 144-168. https://doi.org/10.2458/v25i1.22865

Bluwstein, J. (2019). Resisting legibility: State and conservation boundaries, pastoralism, and the risk of dispossession through geospatial surveys in Tanzania. Rural Landscapes: Society, Environment, History, 6(1), 1-17. http://doi.org/10.16993/rl.53

Bluwstein, J., Lund, J. F., Askew, K., Stein, H., Noe, C., Odgaard, R., Maganga, F., Engstrom, L. (2018). Between dependence and deprivation: The interlocking nature of land alienation in Tanzania. Journal of Agrarian Change, 18(4), 806-830. https://doi.org/10.1111/joac.12271

Braverman, I. (2019). Nof kdumim: Remaking the ancient landscape in East Jerusalem's national parks. Environment and Planning E: Nature and Space, 4(1), 109-134. https://doi.org/10.1177/2514848619889594

Brehony, P., Bluwstein, J., Lund, J. F., \& Tyrrell, P. (2018). Bringing back complex socio-ecological realities to the study of CBNRM impacts: A response to Lee and Bond (2018). Journal of Mammalogy, 99(6), 1539-1542. https://doi.org/10.1093/jmammal/gyy118

Brockington, D. (2002). Fortress conservation: The preservation of the Mkomazi Game Reserve, Tanzania. Indiana University Press, James Currey.

Brockington, D. \& Scholfield, K. (2010). The conservationist mode of production and conservation NGOs in sub-Saharan Africa. Antipode, 42(3), 551-575. https://doi.org/10.1111/j.1467-8330.2010.00763.x

Brooks, T. M., Mittermeier, R. A., da Fonseca, G. A. B., Gerlach, J., Hoffmann, M., Lamoreux, J. F., Mittermeier, C. G., Pilgrim, J. D., Rodrigues, A. S. L. (2006). Global biodiversity conservation priorities. Science, 313(5783), 58-61. https://doi.org/10.1126/science.1127609

Calvert, P. (2001). Internal colonisation, development and environment. Third World Quarterly, 22(1), 51-63.

Clay, N. (2019). Fixing the ecosystem: Conservation, crisis and capital in Rwanda's Gishwati Forest. Environment and Planning E: Nature and Space, 2(1), 23-46. https://doi.org/10.1177/2514848619826576

Clay, N. (2016). Producing hybrid forests in the Congo Basin: A political ecology of the landscape approach to conservation. Geoforum, 76, 130-141. https://doi.org/10.1016/j.geoforum.2016.09.008

Cosgrove, D. E. (1985). Prospect, perspective and the evolution of the landscape idea. Transactions of the Institute of British Geographers, 10(1), 45-62. https://doi.org/10.2307/622249

Cosgrove, D. E. (1984). Social formation and symbolic landscape. Madison: University of Wisconsin Press.

Cronon, W. (1996). The trouble with wilderness: Or, getting back to the wrong nature. Environmental History, 1(1), 7-28. https://doi.org/10.2307/3985059

Dalton, C., Wilmott, C., Fraser, E., Thatcher, J. (2019). "Smart" discourses, the limits of representation, and new regimes of spatial data. Annals of the American Association of Geographers, 110(2), 485-496. https://doi.org/10.1080/24694452.2019.1665493

Davis, D. K. (2007). Resurrecting the granary of Rome: environmental history and French colonial expansion in North Africa. Ohio University Press.

Davis, D. K., \& Burke, E. (2011). Environmental imaginaries of the Middle East and North Africa. Ohio University Press. 
de Leeuw, S., \& Hunt, S. (2018). Unsettling decolonizing geographies. Geography Compass, 12(7), e12376. https://doi.org/10.1111/gec3.12376

Debarbieux, B. (2011). The political meaning of landscape (through the lens of Hannah Arendt's The Human Condition). In Malpas, J. (ed), The place of landscape. (pp. 131-150). MIT Press.

DeFries, R., \& Rosenzweig, C. (2010). Toward a whole-landscape approach for sustainable land use in the tropics. Proceedings of the National Academy of Sciences, 107(46), 19627-19632. https://doi.org/10.1073/pnas.1011163107

Dempsey, J. (2016). Enterprising nature: economics, markets, and finance in global biodiversity politics. Wiley.

Denier, L., Scherr, S., Shames, S., Chatterton, P., Hovani, L., \& Stam, N. (2015). The little sustainable landscapes book: Achieving sustainable development through integrated landscape management. Global Canopy Programme. Oxford.

Dunlap, R. E., \& Brulle, R. J. (2015). Climate change and society: Sociological perspectives. Oxford University Press.

Echeverri, J. A. \& Román-Jitdutjaaño, O. E. (2013). Ash salts and bodily affects: Witoto environmental knowledge as sexual education. Environmental Research Letters, 8(1), 015034. https://doi.org/10.1088/1748-9326/8/1/015034

Eeden, J. V. (2004). The colonial gaze: Imperialism, myths, and South African popular culture. Design Issues, 20(2), 18-33. https://doi.org/10.1162/074793604871266

Estrada-Carmona, N., Hart, A. K., DeClerck, F. A. J., Harvey, C. A., \& Milder, J. C. (2014). Integrated landscape management for agriculture, rural livelihoods, and ecosystem conservation: An assessment of experience from Latin America and the Caribbean. Landscape and Urban Planning, 129: 1-11. https://doi.org/10.1016/j.landurbplan.2014.05.001

Etkind, A. (2013). Internal colonization: Russia's imperial experience. Polity Press.

Evans, M. C. (2021). Re-conceptualizing the role(s) of science in biodiversity conservation. Environmental Conservation, 1-10. https://doi.org/10.1017/S0376892921000114

Fairhead, J., \& Leach, M. (1996). Misreading the African landscape: Society and ecology in a forest-savanna mosaic. Cambridge University Press.

Fairhead, J., Leach, M., \& Scoones, I. (2012). Green Grabbing: a new appropriation of nature? Journal of Peasant Studies, 39(2), 237-261. https://doi.org/10.1080/03066150.2012.671770

Ferguson, J. (1990). The anti-politics machine: "development," Depoliticization, and Bureaucratic Power in Lesotho. University of Minnesota Press.

Ferguson, J. (2015). Give a man a fish: Reflections on the new politics of distribution. Duke University Press.

Fernandez-Armesto, F., \& Muldoon, J. (2017). Internal colonization in Medieval Europe. Taylor \& Francis.

Ford, C. (2008). Reforestation, landscape conservation, and the anxieties of empire in French colonial Algeria. The American Historical Review, 113(2), 341-362. https://doi.org/10.1086/ahr.113.2.341

Foucault, M. (2003). Society must be defended: Lectures at the Collège de France. Trans. David Macey. Picador.

Friess, D. A., \& Jazeel, T. (2017). Unlearning "Landscape." Annals of the American Association of Geographers, 107(1), 14-21. https://doi.org/10.1080/24694452.2016.1230414

García-Martín, M., Bieling, C., Hart, A., \& Plieninger, T. (2016). Integrated landscape initiatives in Europe: Multi-sector collaboration in multi-functional landscapes. Land Use Policy, 58, 43-53. https://doi.org/10.1016/j.landusepol.2016.07.001

Goldman, M. (2003). Partitioned nature, privileged knowledge: Community-Based Conservation in Tanzania. Development and Change, 34(5), 833-862. https://doi.org/10.1111/j.1467-7660.2003.00331.x

Goldman, M. (2020). Narrating nature: Wildlife conservation and Maasai ways of knowing. University of Arizona Press.

Görg, C. (2007). Landscape governance: The "politics of scale" and the "natural" conditions of places. Geoforum, 38(5), 954-966. https://doi.org/10.1016/j.geoforum.2007.01.004

Gregory, D. (1995). Imaginative geographies. Progress in Human Geography, 19(4), $447-485$. https://doi.org/10.1177/030913259501900402

Gregory, D. (2001). Postcolonialism and the production of nature. In Castree, N. \& Braun, B. (eds) Social nature: Theory, practice, and politics. (pp.84-107). Wiley-Blackwell. 
Groening, G. (2007). The "Landscape must become the law"—or should it? Landscape Research, 32(5), 595612. https://doi.org/10.1080/01426390701552746

Grove, R. H. (1996). Green imperialism: Colonial expansion, tropical island Edens and the origins of environmentalism, 1600-1860: Cambridge University Press.

Grosfoguel, R. (2007). The epistemic decolonial turn. Cultural Studies, 21, 211-223. https://doi.org/10.1080/09502380601162514

Guyer, J., \& Richards, P. (1996). The invention of biodiversity: social perspectives on the management of biological variety in Africa. Africa, 66(1), 1-13. https://doi.org/10.2307/1161508

Healy, R., Dal Lago, E., \& Dal Lago, E. (2014). The shadow of colonialism on Europe's modern past. Palgrave Macmillan.

Heckenberger, M. (2013). Who is Amazonia? The 'salt of the matter' for indigenous sustainability. Environmental Research Letters, 8(4), 041007. https://doi.org/10.1088/1748-9326/8/4/041007

Helfenstein, J., Bauer, L., Clalüna, A., Bolliger, J., \& Kienast, F. (2014). Landscape ecology meets landscape science. Landscape Ecology, 29(7), 1109-1113. https://doi.org/10.1007/s10980-014-0055-6

Igoe, J. (2017). Spectacle of nature: On images, money, and conserving capitalism. University of Arizona Press.

Igoe, J., \& Brockington, D. (1999). Pastoral land tenure and community conservation: a case study from NorthEast Tanzania. IIED

Igoe, J., \& Croucher, B. (2007). Conservation, commerce, and communities: The story of community-based wildlife management areas in Tanzania's Northern tourist circuit. Conservation \& Society, 5(4), 534561.

Iordachescu, G. (2021). Becoming a virgin forest: From remote sensing to erasing environmental history. Arcadia, (Spring 2021), no. 10. Rachel Carson Center for Environment and Society. http://www.environmentandsociety.org/node/9254

IUCN (1978). Categories, objectives and criteria for protected areas. Committee on Criteria and Nomenclature. Commission on National Parks and Protected Areas. IUCN.

Jongman, R. H. G., Külvik, M., \& Kristiansen, I. (2004). European ecological networks and greenways. Landscape and Urban Planning, 68(2), 305-319. https://doi.org/10.1016/S0169-2046(03)00163-4

Kühne, O., Weber, F., Berr, K., \& Jenal, C. (eds.). (2019). Handbuch landschaft. Springer VS.

Kühne, O., Weber, F., \& Jenal, C. (2019). Neue landschaftsgeographie. In Kühne, O., Kinder, S. \& Schnur, O. (eds.), Handbuch landschaft. (pp. 119-134). Springer VS.

Lekan, T., \& Zeller, T. (2014). Region, scenery, and power: cultural landscapes in environmental history. In A. C. Isneberg (ed.), The Oxford Handbook of environmental history, (pp. 332-365). Oxford University Press.

Levins, R. (1969). Some demographic and genetic consequences of environmental heterogeneity for biological control. American Entomologist, 15(3), 237-240. https://doi.org/10.1093/besa/15.3.237

Li, T. M. (2007). The will to improve: Governmentality, development, and the practice of politics. Duke University Press.

Lowenthal, D. (2007). Living with and looking at landscape. Landscape Research, 32(5), $635-656$. https://doi.org/10.1080/01426390701552761

MacArthur, R. H., \& Wilson, E. O. (1967). The theory of island biogeography: Princeton University Press.

Malpas, J. (2011). The place of landscape: Concepts, contexts, studies. MIT Press.

Mansfield, B. (2009). Sustainability. In Castree, N., Demeritt, D., Liverman, D. \& Rhoads, B. (eds), A companion to environmental geography. (pp. 37-49). Wiley.

Massey, D. (2005). For space. Sage.

Mbembe, A. (2015). Decolonizing knowledge and the question of the archive. Wits Institute for Social and Economic Research (WISER), University of the Witwatersrand, Johannesburg.

McCall, M. K. (2016). Beyond "landscape" in REDD+: the imperative for "territory." World Development, 85, 58-72. https://doi.org/10.1016/j.worlddev.2016.05.001

McCubbin, S. G. \& Hovorka, A. J. (2020). Visioning African lionscapes: Securing space, mobilizing capital, and fostering subjects. Environment and Planning E: Nature and Space, 3, 1053-1073. https://doi.org/10.1177/2514848619878167

Mignolo, W. (2011). The darker side of western modernity: Global futures, decolonial options. Duke University Press. 
Milder, J. C., Hart, A. K., Dobie, P., Minai, J., \& Zaleski, C. (2014). Integrated landscape initiatives for African agriculture, development, and conservation: A region-wide assessment. World Development, 54, 6880. https://doi.org/10.1016/j.worlddev.2013.07.006

Minca, C. (2007a). Humboldt's compromise, or the forgotten geographies of landscape. Progress in Human Geography, 31(2), 179-193. https://doi.org/10.1177/0309132507075368

Minca, C. (2007b). The tourist landscape paradox. Social \& Cultural Geography, 8(3), $433-453$. https://doi.org/10.1080/14649360701488906

Mitchell, T. (1991). Colonising Egypt. University of California Press.

Mitchell, D. (2001). The lure of the local: landscape studies at the end of a troubled century. Progress in Human Geography, 25(2), 269-281. https://doi.org/10.1191/030913201678580520

Mitchell, D. (2002). Cultural landscapes: the dialectical landscape - recent landscape research in human geography. Progress in Human Geography, 26(3), 381-389. https://doi.org/10.1191/0309132502ph376pr

Mitchell, D. (2003). Cultural landscapes: just landscapes or landscapes of justice? Progress in Human Geography, 27(6), 787-796. https://doi.org/10.1191/0309132503ph464pr

Mollett, S. \& Kepe T. (2018). Land rights, biodiversity conservation and justice: Rethinking parks and people. Routledge.

Moon, D. (2018). Planting trees in unsuitable places: Russian steppe forestry, 1696-1850. In Breyfogle, N. (ed), Eurasian Environments: Nature and ecology in imperial Russian and Soviet history. (pp. 23-42). University of Pittsburgh Press.

Moreno, C., S., C. D., \& Fuhr, L. (2015). Carbon metrics - global abstractions and ecological epistemicide. Heinrich Böll Stiftung

Myers, N. (1972). National parks in savannah Africa. Science, 178(4067), 1255-1263. https://doi.org/10.1126/science.178.4067.1255

Myers, N. (1988). Threatened biotas: "hot spots" in tropical forests. Environmentalist, 8(3),187-208. https://doi.org/10.1007/BF02240252

Ndlovu-Gatsheni, S. J. (2015). Decoloniality as the future of Africa. History Compass, 13, $485-496$. https://doi.org/10.1111/hic3.12264

Neumann, R. P. (1998). Imposing wilderness: Struggles over livelihood and nature preservation in Africa. University of California Press.

Neumann, R. P. (2002). The postwar conservation boom in British colonial Africa. Environmental History, 7(1), 22-47. https://doi.org/10.2307/3985451

Neumann, R. P. (2011). Political ecology III: Theorizing landscape. Progress in Human Geography, 35(6), 843-850. https://doi.org/10.1177/0309132510390870

Noe, C. (2010). Spatiality and 'borderlessness' in transfrontier conservation areas. South African Geographical Journal, 92(2), 144-159. https://doi.org/10.1080/03736245.2010.525079

Noe, C. (2019). The Berlin curse in Tanzania:(re)making of the Selous world heritage property. South African Geographical Journal, 101(3), 379-398. https://doi.org/10.1080/03736245.2019.1645039

Okoye, I.S. (2016). Good Bush, Bad Bush. Representing our natures in historical Southern Nigerian Landscapes. In Beardsley, J. (ed). Cultural landscape heritage in Sub-Saharan Africa. (pp. 263-292). Dumbarton Oaks Research Library and Collection.

Olwig, K. (2002). Landscape, nature, and the body politic: from Britain's renaissance to America's new world. University of Wisconsin Press.

Olwig, K. \& Mitchell, D. (2007). Justice, power and the political landscape: From American space to the European Landscape Convention. Landscape Research, 32(5), 525-531. https://doi.org/10.1080/01426390701552688

Pinderhughes, C. (2011). Toward a new theory of internal colonialism. Socialism and Democracy, 25(1), 235256. https://doi.org/10.1080/08854300.2011.559702

Plumwood, V. (2003). Decolonizing relationships with nature. In Adams, W. M. \& Mulligan, M. (eds.), Decolonizing nature: strategies for conservation in a post-colonial era. (pp. 51-78). Earthscan.

Poerting, J., \& Marquardt, N. (2019). Kritisch-geographische perspektiven auf landschaft. In O. Kühne, S. Kinder, \& O. Schnur (eds.), Handbuch landschaft. (pp. 145-152). Springer VS.

Ramutsindela, M. (2007). Transfrontier conservation in Africa: At the confluence of capital, politics and nature. CABI. 
Ramutsindela, M. (2016). "Nature's Regions." The mobilization of culural landscapes for conservation. In Beardsley, J. (ed). Cultural landscape heritage in Sub-Saharan Africa. (pp. 379-396). Dumbarton Oaks Research Library and Collection, Washington D.C.

Ramutsindela, M. (2017). Greening Africa's borderlands: The symbiotic politics of land and borders in peace parks. Political Geography 56: 106-113. https://doi.org/10.1016/j.polgeo.2016.11.012

Reed, J., Deakin, L., \& Sunderland, T. (2015). What are 'Integrated Landscape Approaches' and how effectively have they been implemented in the tropics: a systematic map protocol. Environmental Evidence, 4(1), 2. https://doi.org/10.1186/2047-2382-4-2

Reed, J., van Vianen, J., Barlow, J., \& Sunderland, T. (2017). Have integrated landscape approaches reconciled societal and environmental issues in the tropics? Land Use Policy, 63, 481-492. https://doi.org/10.1016/j.landusepol.2017.02.021

Redford, K. H, Coppolillo, P., Sanderson, E. W., et al. (2003). Mapping the conservation landscape. Conservation Biology, 17, 116-131. https://doi.org/10.1046/j.1523-1739.2003.01467.x

Redford, K. H. (2011). Misreading the conservation landscape. Oryx, 45, 324-330. https://doi.org/10.1017/S0030605311000019

Risser, P. G. (1984). Landscape ecology: directions and approaches. Illinois Natural History Survey.

Robson, A. S., Trimble, M. J., Purdon, A., Young-Overton, K. D., Pimm, S. L., \& van Aarde, R. J. (2017). Savanna elephant numbers are only a quarter of their expected values. PLoS ONE, 12(4), e0175942. https://doi.org/10.1371/journal.pone.0175942

Sachedina, H. (2008). Wildlife is our oil: Conservation, livelihoods and NGOs in the Tarangire Ecosystem, Tanzania. (PhD dissertation), University of Oxford.

Sachedina, H., \& Nelson, F. (2010). Protected areas and community incentives in savannah ecosystems: a case $\begin{array}{lllll}\text { study of Tanzania's Maasai Steppe. Oryx, 44(03), 390-398. } & \text { Or }\end{array}$ https://doi.org/10.1017/S0030605310000499

Sachedina, H. T. (2011). Disconnected nature: the scaling up of African Wildlife Foundation and its impacts on biodiversity conservation and local livelihoods. In Brockington, D. \& Duffy, R. (eds.), Capitalism and conservation. (pp. 135-155). Wiley-Blackwell.

Sack, R. D. (1986). Human territoriality: its theory and history. Cambridge University Press.

Said, E. (1979). Orientalism. Vintage.

Sale, K. (1985). Dwellers in the land: the bioregional vision. University of Georgia Press.

Setten, G. (2017). Landscape, temporality and responsibility. Making conceptual connections through alien invasive species. In Head, L., Saltzman, K., Setten, G. \& Stenseke, M. (eds) Nature, temporality and environmental management: Scandinavian and Australian perspectives on peoples and landscapes. (pp. 30-44). Routledge.

Sheridan, M. J. (2009). The environmental and social history of African sacred groves: A Tanzanian case study. African Studies Review, 52 (1), 73-98. https://doi.org/10.1353/arw.0.0149

Scott, J. C. (1998). Seeing like a state: how certain schemes to improve the human condition have failed. Yale University Press.

Sluyter, A. (2001). Colonialism and landscape in the americas: material/conceptual transformations and continuing consequences. Annals of the Association of American Geographers, 91(2), 410-428. https://doi.org/10.1111/0004-5608.00251

Smith, J., Clark, N., \& Yusoff, K. (2007). Interdependence. Geography Compass, 1(3), 340-359. https://doi.org/10.1111/j.1749-8198.2007.00015.x

Smith, L. T. (1999). Decolonizing methodologies: Research and Indigenous peoples. Zed.

Soulé, M. E. (1985). What is conservation biology? BioScience 35(11), 727-734.

Spivak, G. C. (1988). Can the subaltern speak? In Nelson, C. \& Grossberg, L. (eds), Marxism and the interpretation of culture. (pp. 24-28). Macmillan.

Sundberg, J. (1998). NGO landscapes in the Maya biosphere reserve, Guatemala. Geographical Review, 88(3), 388-412. https://doi.org/10.1111/j.1931-0846.1998.tb00114.x

Sundberg, J. (2014) Decolonizing posthumanist geographies. Cultural Geographies, 21, 33-47. https://doi.org/10.1177/1474474013486067

Sunderland, W. (2004). Taming the wild field: colonization and empire on the Russian steppe. Cornell University Press. 
Sungusia, E., Lund, J. F. \& Ngaga, Y. (2020). Decolonizing forestry: overcoming the symbolic violence of forestry education in Tanzania. Critical African Studies, 12(3), 354-371. https://doi.org/10.1080/21681392.2020.1788961

Todd, Z. (2016). An Indigenous feminist's take on the ontological turn: 'Ontology' is just another word for colonialism. Journal of Historical Sociology, 29(1), 4-22. https://doi.org/10.1111/johs.12124

Toomey, A. (2020). The making of a conservation landscape: Towards a practice of interdependence. Conservation and Society, 18(1), 25-36. http://doi.org/10.4103/cs.cs_18_115

Tuck, E. \& Yang, K.W. (2012). Decolonization is not a metaphor. Decolonization: Indigeneity, Education \& Society, 1(1), 1-40.

Turner, J. (2018). Internal colonisation: The intimate circulations of empire, race and liberal government. $\begin{array}{lllll}\text { European Journal of International Relations, 24(4), } & \text { 765-790. }\end{array}$ https://doi.org/10.1177/1354066117734904

Turnhout, E., Metze, T., Wyborn, C., Klenk, N., \& Louder, E. (2020). The politics of co-production: participation, power, and transformation. Current Opinion in Environmental Sustainability, 42, 15-21. https://doi.org/10.1016/j.cosust.2019.11.009

van de Grift, L. (2015). Introduction: Theories and practices of internal colonization. The cultivation of lands and people in the age of modern territoriality. International Journal for History, Culture and Modernity, 3(2), 139-158. https://doi.org/10.18352/hcm.480

Vandergeest, P., \& Peluso, N. L. (1995). Territorialization and state power in Thailand. Theory and Society, 24(3), 385-426. https://doi.org/10.1007/BF00993352

Vasilijević, M., Zunckel, K., McKinney, M., Erg, B., Schoon, M., \& Rosen Michel, T. (2015). Transboundary conservation: A systematic and integrated approach. IUCN, Gland, Switzerland

Weber, F., \& Kühne, O. (2019). Essentialistische Landschafts- und positivistische Raumforschung. In Kühne, O., Kinder, S. \& Schnur, O. (eds), Handbuch Landschaft. (pp. 57-68). Springer VS.

West, P. (2016). Dispossession and the environment: Rhetoric and inequality in Papua New Guinea. Columbia University Press.

West, P., Igoe, J., \& Brockington, D. (2006). Parks and peoples: The social impact of protected areas. Annual Review of Anthropology, 35(1), 251-277. https://doi.org/10.1146/annurev.anthro.35.081705.123308

Willems-Braun, B. (1997). Buried epistemologies: the politics of nature in (post)colonial British Columbia. Annals of the Association of American Geographers, 87, 3-31. https://doi.org/10.1111/00045608.00039

Williams, R. (1975). The country and the city. Oxford University Press.

Wolmer, W. (2003). Transboundary conservation: the politics of ecological integrity in the Great Limpopo Transfrontier Park. Journal of Southern African Studies, 29(1), 261-278. https://doi.org/10.1080/0305707032000060449

Worboys, G., Francis, W. L., \& Lockwood, M. (2010). Connectivity conservation management: A global guide. Earthscan.

Wu, J. (2012). A landscape approach for sustainability science. In Weinstein, P. M. \& Turner, E. R. (eds), Sustainability Science: The emerging paradigm and the urban environment (pp. 59-77). Springer

Wyborn, C. (2015). Connectivity conservation: Boundary objects, science narratives and the co-production of science and practice. Environmental Science \& Policy, 51, 292-303. https://doi.org/10.1016/j.envsci.2015.04.019

Wylie, J. W. (2007). Landscape. Routledge.

Zanzanaini, C., Trần, B. T., Singh, C., Hart, A., Milder, J., \& DeClerck, F. (2017). Integrated landscape initiatives for agriculture, livelihoods and ecosystem conservation: An assessment of experiences from South and Southeast Asia. Landscape and Urban Planning, 165, 11-21. https://doi.org/10.1016/j.landurbplan.2017.03.010

Zimmerer, K. S. (2006). Cultural ecology: at the interface with political ecology - the new geographies of environmental conservation and globalization. Progress in Human Geography, 30(1), 63-78. https://doi.org/10.1191/0309132506ph591pr 